\title{
Single seed analysis of fatty acids and glucosinolates combined with meristem rescue in Brassica campestris $\mathbf{L}$.
}

\author{
SEPPO SORVARI \\ Department of Plant Breeding, Agricultural Research Centre \\ SF-31600 Jokioinen, Finland
}

\begin{abstract}
A method for the simultaneous analysis of fatty acids and glucosinolates in a single seed without loosing the original genome was developed. Loss of the original genome was avoided by dissecting the meristem from the seed germinated short time under sterile conditions and by growing an adult plant from it. The rest of the seed was used for fatty acid and glucosinolate analysis by gas chromatography and high-performance liquid chromatography.
\end{abstract}

Index words: Brassica campestris, meristem culture, glucosinolate analysis, fatty acid analysis, single seed analysis, danzylhydrazine, fluorescent dye

\section{Introduction}

The half seed method has succesfully been used in routine plant breeding since its introduction by Dorrel and Downey in 1964. The outer cotyledon is removed after one or two days of germination, and the fatty acid composition is analysed. The method has contributed to great progress in decreasing some long carbon chain fatty acids, especially erucic acid (C22:1) which has been found harmful in edible oil (BEARE et al. 1959).

Besides erucid acid, the hydrolysis products of glucosinolates cause problems in the utilization of seed meal.

Crushing the cell structures of seed during oil extraction causes hydrolysis of glucosino- lates by the enzyme myrosinase (thioglucosid glucohydrolase E.C. 3.2.3.1.). Some hydrolysis products are toxic and thus restrict the full utilization of flours in nonruminant feed (Bowland et al. 1963).

Because the bulk analysis of glucosinolates was not quite satisfactory, LEIN and SCHÖN (1969) introduced the simultaneous analysis of fatty acids and glucosinolates in the same cotyledon.

The method is based on the measurement of glucose hydrolyzed from glucosinolates by the enzyme myrosinase. After hydrolysis the glucose concentration is then measured at 340 $\mathrm{nm}$ by using an enzymatic analysis method of hexokinase + ATP/Glucose-6-P-dehydrogenase + ATP. 
This method works quite well, but it has some limitations. For instance, the amount of free glucose cannot be determined because of its low concentration in the seed. This is not a problem when working with high glucosinolate types, because the concentration of free glucose, which is less than $4 \mu \mathrm{mol}$ per $1 \mathrm{~g}$ of fat-free meal, comprises only $1 / 8-1 / 20$ of the total glucose content.

In the new low glucosinolate types the amount of free glucose can, however, make up more than half of the total glucose content. Thus the concentration of free glucose must be known if it cannot be removed before hydrolysis of glucosinolates. Using the half seed technique, however, the total glucose concentration remains below the detection limit of the enzymatic system, rendering this method useless.

In glucose analysis, the sensitivity can be increased dramatically by using fluorescent dyes combined with HPLC. Dansylhydrazine, first described by AvigAD (1977), labels specifically and rapidly the reducing ends of sugars with a fluorescent tag. This technique allows the detection of glucose when using UV-detection at the pico gram range. Fluorescence detection increases sensitivity further by about a hundred times.

According to Acharya et al. (1983), the double-zero type contains less than $30 \mu \mathrm{mol}$ glucosinolates per $1 \mathrm{~g}$ of fat-free meal (and less than $5 \%$ erucic acid of the total fatty acid content). In the new double-zero varieties the glucosinolate concentration can, however, be less than $10 \mu \mathrm{mol}$. Also the erucid acid content is nowadays far less than $5 \%$. Such low concentrations are extremely difficult to measure reliably in one cotyledon, but if the whole seed is available there is enough material for relative simple HPLC analysis. On the other hand, also the fatty acid composition measured in the whole seed is similar to that of the fatty acids of the industrially extracted oil.

The purpose of this work was to develop a method for routine plant breeding which allows simultaneous analysis of glucosinolate concentration and fatty acid composition in the single seed without loosing the original genome by dissecting the meristematic dome before analysis and growing a new plant from the meristem.

\section{Material and methods}

\section{Dissection and culture of meristems}

for single germinated seeds

Dry seeds of the yellow seed low erucic and glucosinolate line 45682 [(dihaploid Candlex Torch) $\times$ Candle] with a moisture content of about $5 \%$ were weighed at an accuracy of $0,1 \mathrm{mg}$, sterilized with $10 \%$ sodium hypochlorite and germinated on sterilized and moistened filter paper on a Petri dish in darkness at $25^{\circ} \mathrm{C}$ for 20 hours. After germination, the meristems were dissected under sterile conditions and transferred to hormone-free B5 medium containing $2 \%$ sucrose (GAMBORG et al. 1968, Table 1). The culture tubes or Petri dishes were kept in darkness at $25^{\circ} \mathrm{C}$ for $1-2$ weeks, thereafter under illumination (3000 lux, $18 \mathrm{~h} / \mathrm{day}, 25^{\circ} \mathrm{C}$ ) for $2-4$ weeks. After this period the plants were ready for potting or cloning for further experiments.

\section{Single seed analysis of glucosinolates} by $\mathrm{HPLC}$

Myrosinase (thioglucosid glucohydrolase

Table 1. Composition of B5 medium used for meristem cultures of Brassica campestris.

\begin{tabular}{|c|c|c|c|}
\hline Component & $\mathrm{mg} / 1$ & Component & $\mathrm{mg} / \mathrm{l}$ \\
\hline \multirow{5}{*}{$\begin{array}{l}\mathrm{KNO}_{3} \\
\left(\mathrm{NH}_{4}\right)_{2} \mathrm{SO}_{4} \\
\mathrm{NaH}_{2} \mathrm{PO}_{4} \cdot \mathrm{H}_{2} \mathrm{O} \\
\mathrm{CaCl}_{2} \cdot 2 \mathrm{H}_{2} \mathrm{O} \\
\mathrm{MgSO}_{4} \cdot 7 \mathrm{H}_{2} \mathrm{O}\end{array}$} & 2500 & $\mathrm{FeSO}_{4} \cdot 7 \mathrm{H}_{2} \mathrm{O}^{*}$ & 27,8 \\
\hline & 134 & NA-EDTA * & 37,3 \\
\hline & 150 & Nicotinic acid & 1,0 \\
\hline & 750 & Thiamine $\mathrm{HCl}$ & 10,0 \\
\hline & 250 & Pyridoxine $\mathrm{HCl}$ & 1,0 \\
\hline $\mathrm{MnSO}_{4} \cdot 4 \mathrm{H}_{2} \mathrm{O}$ & 7,6 & m-Inositol & 100,0 \\
\hline $\mathrm{H}_{3} \mathrm{BO}_{3}$ & 3,0 & Glutamine & 800,0 \\
\hline $\mathrm{ZnSO}_{4} \cdot 7 \mathrm{H}_{2} \mathrm{O}$ & $\begin{array}{l}2,0 \\
0,75\end{array}$ & Serine & 100,0 \\
\hline $\begin{array}{l}\mathrm{KJ} \\
\mathrm{Na}_{2} \mathrm{MoO}_{4} \cdot 2 \mathrm{H}_{2}\end{array}$ & $\begin{array}{l}0,75 \\
0,25\end{array}$ & Sucrose & $2,0^{\circ}$ \\
\hline $\begin{array}{l}\mathrm{Na}_{2} \mathrm{MOO}_{4} \cdot 2 \mathrm{H}_{2} \mathrm{O} \\
\mathrm{CuSO}_{4} \cdot 5 \mathrm{H}_{2} \mathrm{O}\end{array}$ & 0,04 & Agar (Difco Noble) & $0,8^{\circ}$ \\
\hline $\mathrm{CoCl}_{2} \cdot 6 \mathrm{H}_{2} \mathrm{O}$ & 0,025 & $\mathrm{pH}$ & 5,8 \\
\hline
\end{tabular}

* For preparation of NaFe-EDTA solution see Muras. HIGE and SKOOG (1962) 
E.C. 3.2.3.1.) was prepared with modifications according to a modified method of Schwimmer (1961). $100 \mathrm{~g}$ of dry (ca. $5 \%$ moisture) white mustard seeds were ground in a coffee grinder for one minute. The powder was extracted twice with $300 \mathrm{ml}$ of petroleum benzine and vacuum-dried on a "Büchner» funnel. The dry defatted powder was extracted once with $400 \mathrm{ml}$ of water for 1 hour, mixing vigorously all the time with a Morat R30SL mixer. The residue was removed by centrifugation at $6000 \mathrm{xg}$.

The supernatants were combined and the first precipitation was carried out with acetone by raising its concentration in the extract to $30 \%$. The precipitate was removed by centrifugation $(6000 \mathrm{xg})$, the supernatants were combined again and precipitated by adding more acetone. The fraction precipitating between $30 \%-70 \%$ was collected and rinsed twice with water. The watery myrosinase solution was dialysed against $1 \% \mathrm{NaCl}$ solution for 24 hours, $0,5 \% \mathrm{NaCl}$ solution for 8 hours and water for 24 hours. The extraction of myrosinase was performed in an ice bath. The dialysed myrosinase solution was freezedried, and the white enzyme preparation was stored in a deep-freezer $\left(-20^{\circ} \mathrm{C}\right)$.

Preparation of single seed samples for glucosinolate analysis was carried out with modified methods of APPELQVIST \& JOSEFSSON (1967), Lein \& Schön (1969), Jürges \& Thies (1980), Heaney \& Fenwick (1981) and Daun \& McGregor (1981). After dissection of meristems, endogenous myrosinase was inactivated by placing the seeds into centrifuge tubes and keeping them for 15 minutes in a hot $\left(>95^{\circ} \mathrm{C}\right) 0,1 \mathrm{M}$ tris/ $\mathrm{HCl}$ buffer $(\mathrm{pH} \mathrm{7,2})$. The buffer was then discarded, and the seeds were dried overnight at $65^{\circ} \mathrm{C}$. The dried seed samples were cooled and ground with a glass rod in $1 \mathrm{ml}$ of petroleum benzine.

The ground samples were centrifuged at $5000 \mathrm{xg}$ and defatted two more times with $1 \mathrm{ml}$ of petroleum benzine and by centrifugations at $5000 \mathrm{xg}$. (The first petroleum benzine extract can also be used for the determination of fatty acids). The supernatants were dis- 
carded, and the remaining petroleum benzine in the seed meal was evaporated in vacuum.

The extraction of glucosinolates was done by placing the tubes into a hot $\left(>95^{\circ} \mathrm{C}\right)$ water bath, adding hot $\left(>95^{\circ} \mathrm{C}\right)$ tris $/ \mathrm{HCl}$ buffer $(0,1 \mathrm{M}, \mathrm{pH} 7,2)$ and incubating the samples for 5 minutes. After incubation, the samples were cooled to room temperature, and $200 \mu \mathrm{l}$ of $0,5 \%$ myrosinase in tris/ $\mathrm{HCl}(0,1 \mathrm{M}, \mathrm{pH}$ $7,2)$, and $200 \mu \mathrm{l}$ of $2 \%$ ascorbic acid in tris/ $\mathrm{HCl}(0,1 \mathrm{M}, \mathrm{pH} 7,2)$ were added while mixing cautiously the samples and then incubated for 3 hours at $40^{\circ} \mathrm{C}$.

Hydrolysis was stopped with $800 \mu \mathrm{l}$ deepfreezer cold $\left(-20^{\circ} \mathrm{C}\right)$ absolute ethanol, by centrifugation of the precipitate at $5000 \mathrm{xg}$ for 15 minutes. Thereafter the supernatant was pipetted into autosampler vials. The samples were dried at $65^{\circ} \mathrm{C}$ under continuous nitrogen flow. After drying for about 30 minutes, the vials were closed with screw caps and stored in a deep-freezer $\left(-20^{\circ} \mathrm{C}\right)$ until analysis.

The influence of germination time on glucosinolate content was studied by germinating ca. $200 \mathrm{mg}$ of seeds of the line 45682 in darkness at $25^{\circ} \mathrm{C}$ on moistened filter paper on Petri dishes. Germination was stopped at invervals of 10, 20, 32 and 48 hours by keeping the samples in a hot $\left(>95^{\circ} \mathrm{C}\right)$ tris $/ \mathrm{HCl}$ buffer $(0,1 \mathrm{M}, \mathrm{pH} 7,2)$ for 5 minutes and drying them at $65^{\circ} \mathrm{C}$ overnight. About $200 \mathrm{mg}$ of dried seed sample was homogenized in a glass tissue homogenizer with $5 \mathrm{ml}$ of petroleum benzine. Homogenized tissue was transferred into a centrifuge tube and centrifuged at ca. $4000 \mathrm{xg}$. The petroleum benzine was decanted, oil extraction by centrifugation was repeated twice, and the meal was then dried in vacuum.

For hydrolysis, $5 \mathrm{mg}$ of the meal samples were weighed and hydrolyzed as described previously for single seed analysis. Free glucose was extracted with $800 \mu \mathrm{l}$ tris/ $\mathrm{HCl}(0,1 \mathrm{M}, \mathrm{pH}$ 7,2 ) for 3 hours under the same conditions as those for hydrolysis, but without myrosinase or ascorbic acid.

In this system, the determination of glucosinolate is based on the measurement of the

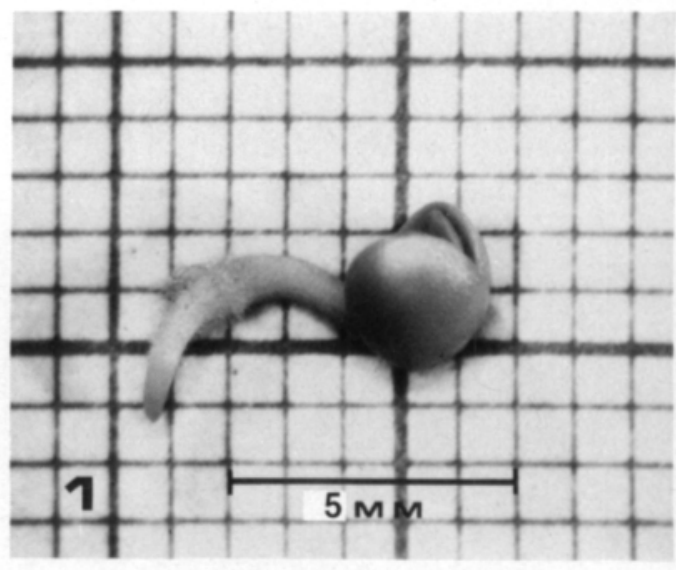

Fig. 1. Seed of Brassica campestris line 45682 germinated for about one day.

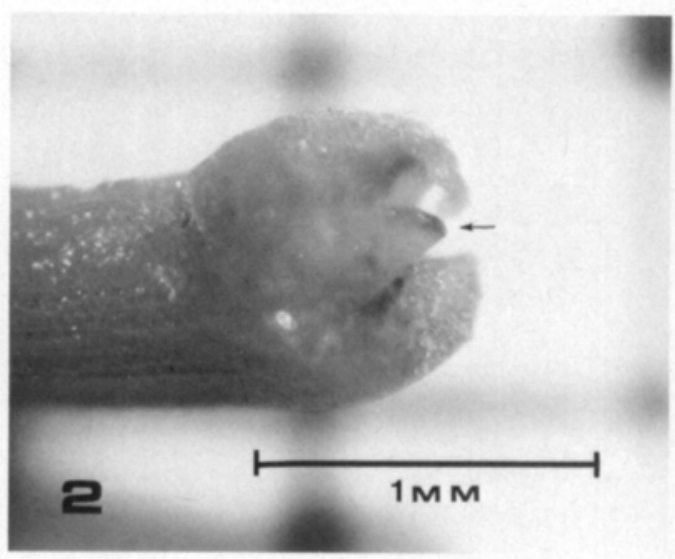

Fig. 2. Hypocotyl without cotyledons of Brassica campestris line 45682 . Meristematic dome shown by an arrow.

glucose hydrolyzed from glucosinolates by the enzyme myrosinase into the aqueous solution. Glucose in the dried samples was labelled with UV-absorbing 5-dimethylaminonaphthalene1-sulphonylhydrazine (Dns-hydrazine) according to the method described by AvigAD (1977) and modified by AlPenfels (1981), MOPPER \& Johansson (1983) and Eggert \& Jones (1985).

To the dried samples, $12 \mu \mathrm{l}$ of $10 \%$ trichloroacetic acid (TCA), $10 \mu \mathrm{l}$ of $0,05 \mathrm{M}$ lyxose as internal standard and $200 \mu \mathrm{l}$ of $2 \%$ Dansylhydrazine were added. The vials were capped with screw caps, the samples mixed to a few seconds and then derivatized at $65^{\circ} \mathrm{C}$ 
for 20 minutes. The reaction was stopped by cooling the vials under running tap water.

For purification of samples, a Sep-Pak cartridge was activated with $4 \mathrm{ml}$ of acetonitrile and $4 \mathrm{ml}$ of water. The reaction mixture was diluted with $1 \mathrm{ml}$ of water and loaded onto the Sep-Pak. The solution was pumped through the cartridge which was then rinsed with $2 \mathrm{ml}$ of $10 \%$ acetonitrile. After rinsing the derivative was eluted with $2 \mathrm{ml}$ of $40 \%$ acetonitrile and analyzed immediately by HPLC. The Sep-Pak was regenerated by rinsing with $2 \mathrm{ml}$ of acetonitrile:methanol (2:8), followed by $2 \mathrm{ml}$ of acetonitrile and 2 $\mathrm{ml}$ of water.

The analysis was performed with a PerkinElmer 3D HPLC system combined with a Perkin-Elmer HS-3 C 18 column and a Perkin-Elmer LCI 100 integrator. The chromatographic conditions for separation of glucose and lyxose derivatives were isocratic at a flowrate of $1 \mathrm{ml} / \mathrm{min}$. The solvent was $20 \%$ acetonitrile containing $0,001 \mathrm{M}$ of triethylamine, $0,04 \mathrm{M}$ of acetic acid and $0,01 \mathrm{M}$ of formic acid. Between sample injections the column was cleaned for 25 minutes with the solvent. The time required for separation of the derivatives was about 13 minutes.

\section{Single seed analysis of fatty acids by gas chromatography}

Fatty acid analyses were performed with modifications of the method described by THIEs (1968). Seeds of the line 45682 were germinated in darkness at $25^{\circ} \mathrm{C}$ on moistened filter papers on Petri dishes for 20 hours. The outer and inner cotyledons were dissected and inserted into test tubes $(16 \times 100 \mathrm{~mm}$, Pyrex with screw cap). After addition of $2 \mathrm{ml}$ of a mixture consisting of $60 \%$ methanolic sodium hydroxide solution $(0,4 \mathrm{~g} \mathrm{NaOH}$ in 1000 $\mathrm{ml}$ methanol) and $40 \%$ petroleum benzine (bp $40-60^{\circ} \mathrm{C}$ ), the cotyledons were crushed with a glass rod. The extracts were incubated overnight at room temperature, acidified with a solution containing $8 \% \mathrm{NaCl}$ and $0.3 \%$ $\mathrm{NaHSO}_{4}$ in water, and shaken vigorously.

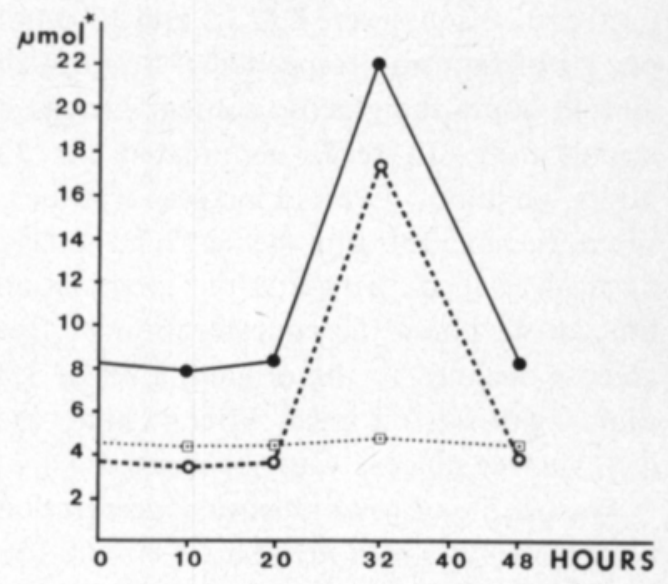

Fig. 3. Changes of free, total and glucosinolate-glucose concentrations during germination of low glucosinolate line 45682 of Brassica campestris.

* Glucose/glucosinolate concentration per $1 \mathrm{~g}$ of fatfree meal (fat content $40 \%$, moisture $5 \%$ )

- Concentration of total glucose

- Concentration of free glucose

- Concentration of glucose hydrolyzed from glucosinolates

From the two phases formed, the upper petroleum benzine layer was pipetted into another test tube and evaporated in a water bath to dryness. To the sample, $50 \mu \mathrm{l}$ of petroleum benzine was added, and $1 \mu \mathrm{l}$ of the solution was injected with a Hamilton RN 701 syringe into the column.

The samples were chromatographed on a Perkin-Elmer Sigma 1 gas chromatograph equipped with a flame ionization detector (FID). The column used was $25 \mathrm{~m} \times 0,2 \mathrm{~mm}$ FFAP vitreous silica purchased from SGE (Scientific Glass Engineering Pty., Ltd. Australia). The chromatograms were processed by a Perkin-Elmer Sigma 10 Data Station. The composition of fatty acids is given in Table 14 as percentages of total fatty acids.

\section{Results}

\section{Glucosinolate analysis}

During the first 20 hours the concentration of free glucose was stable (Fig. 3). The concentrations measured in seeds germinated for 
0,10 and 20 hours were $3,6,3,5$ and $3,7 \mu \mathrm{mol}$ per $1 \mathrm{~g}$ of fat meal, respectively. Between 20 and 48 hours the glucose content increased dramatically. In seeds germinated for 32 hours, an almost fivefold increase was measured, the concentration being $17,3 \mu \mathrm{mol} / 1 \mathrm{~g}$ of fat-free meal. Towards the germination time of 48 hours the concentration of free glucose declined to the original level of 3,8 $\mu \mathrm{mol} / \mathrm{g}$ of fat-free meal. After 48 hours the level of free glucose was not measured.

The profile of total glucose concentration after hydrolysis with myrosinase strictly followed that of free glucose but was naturally higher. The total glucose concentrations after germinations for $0,10,20,32$ and 48 hours were $8,2 \mu \mathrm{mol}, 7,9 \mu \mathrm{mol}, 8,4 \mu \mathrm{mol}, 22,1 \mu \mathrm{mol}$ and $8,3 \mu \mathrm{mol} / 1 \mathrm{~g}$ of fat-free meal, respectively. Thus the glucosinolate concentration, i.e. the difference between total and free glucose concentrations, $4,6 \mu \mathrm{mol}, 4,4 \mu \mathrm{mol}$, $4,7 \mu \mathrm{mol}, 4,8 \mu \mathrm{mol}$ and $4,5 \mu \mathrm{mol}$, respectively, did not change during the germination time of 48 hours.

The glucosinolate concentration measured in a single seed was steadily lower than the 4,6 $\mu \mathrm{mol}$ measured in the standard meal (Fig. 4). This is due mainly to the absence of meristem.

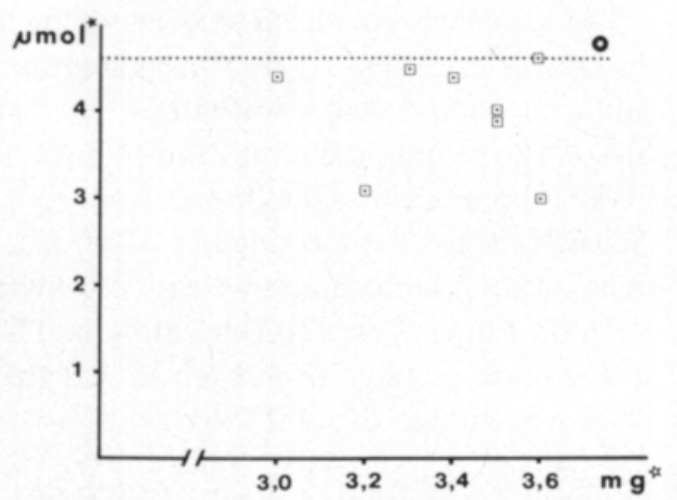

Fig. 4. Concentrations of glucosinolates in single seeds of low glucosinolate line 45682 of Brassica campestris.

* Glucosinolate concentration per $1 \mathrm{~g}$ of fat-free meal (fat content $40 \%$, moisture $5 \%$ )

- Seed weight

Glucosinolate concentration of standard meal
In addition, grinding the seed with a glass rod is not a sufficiently effective technique, as a certain number of the cells may remain intact in the sample, thus diminishing the concentration of the extract obtained.

The glucosinolate concentration in the single seeds was within the range of 3,0$4,6 \mu \mathrm{mol}$, mean $4,0 \mu \mathrm{mol}$, i.e. $0,6 \mu \mathrm{mol}$ less than in the standard meal.

Because oleic, linoleic and linolenic acids comprise over $90 \%$ of the total fatty acids, differences in their concentrations between the outer and the inner cotyledons are most important (Table 2). The oleic acid concentration of the outer cotyledon was normally 2,4 $-8,0 \%$ higher than that of the inner cotyledon. The inner cotyledons of seeds No 5 and 8 had oleic acid concentrations of $5,1 \%$ and $2,0 \%$ higher, respectively, than the outer cotyledons. The linoleic acid concentrations of the outer cotyledons $(0,9-2,8 \%)$ were higher than those of the inner ones.

When comparing oleic and linoleic acid concentrations, the linoleic acid concentration was, on the contrary, lower in the outer than in the inner cotyledons, ranging from 0,3 to $7,2 \%$. The other fatty acids, being of low concentrations, had a minor influence on the total fatty acid composition.

Dissection and culture of meristems could be carried out routinely without problems.

After sterilization there was no contamination in the subsequent germination, meristem dissection and culture because of the compact structure of the seeds, and the recovery of plants was $100 \%$.

\section{Discussion}

The half seed technique has long been employed in the routine analysis of fatty acids (Dorrel \& Downey 1964). The seeds are germinated for about two days, thereafter the outer cotyledon is dissected and its fatty acid composition analyzed by gas chromatography. The method has been further elaborated by LEIN and SCHön (1969) who presented the simultaneous analysis of fatty acids and 
glucosinolates in the same cotyledon. The glucose hydrolyzed from glucosinolate via the enzyme myrosinase was measured by the enzymatic system hexokinase + ATP/Glucose6-P-dehydrogenase + NADP at $340 \mathrm{~nm}$, as mentioned previously.

For preparation of the glucosinolate samples, there is another rather sophisticated technique that is based on binding the glucosinolates onto a DEAE Sephadex A25 anion exchanger followed by hydrolysis with myrosinase (Thies 1976, Jürges \& Thies 1980, Heaney \& FEnwiCK 1981). Free glucose is washed away before hydrolysis after which the glucose released can be measured. Thus no analysis of free glucose is necessary.

In the present study, however, it was decided to apply direct hydrolysis of the sample in the test tube. The method may be more suitable for routine plant breeding, because it is simple and rapid. In routine work, where hundreds of samples are analyzed, it is recommended to use a higher centrifugal force in the range of $10000-15000 \mathrm{xg}$, because the proteins and other relative high molecular weight impurities, which remain in the sample after low force centrifugation, may clog the column. The impurity problem can also be solved by addition of an extra purification step with Sep-Pak after centrifugation and evaporation. This step is however very time consuming because it requires a second evaporation step before derivatization.

Derivatization with dansylhydrazine being influenced by water (MOPPER \& JOHANSSON 1983), a minimal amount of water was used. The derivatization temperature of $80^{\circ} \mathrm{C}$, used by Alpenfels (1981), sometimes caused negative changes in the sample, turning them dark brown. The reaction temperature of $65^{\circ} \mathrm{C}$ took 20 minutes, but was more reliable than 10 minutes at $80^{\circ} \mathrm{C}$.

Purification of the derivatized sample with Sep-Pak is necessary, because according to EgGert \& Jones (1985), deterioration of column performance can be thus prevented. In addition to trichloroacetic acid, other hydrophilic substances were removed, but all dan- sylhydrazine residues could not be removed in this way. Due to dilution caused by elution with water, problems of detection may arise also when working at extremely low glucose concentrations. Concentration of the derivatized sample should be avoided because of the instability of derivatized glucose and lyxose. Especially lyxose is very unstable. According to EgGert \& Jones (1985) the loss of lyxosedansyl derivative at $20^{\circ} \mathrm{C}$ per 1 hour is $6,4 \%$, whereas the loss for glucose is $1,1 \%$.

Because unchanged dansylhydrazine residues could not be removed by the Sep-Pak treatment, a rather long cleaning treatment of the column was necessary. The mixture of $20 \%$ (v/v) acetonitrile and $80 \%(\mathrm{v} / \mathrm{v})$ methanol was not suitable here because the stabilization of the column after the cleaning process required several hours. Satisfactory results were obtained by cleaning between sample injections with running solvent for $\mathbf{2 0}$ minutes at a constant flow-rate of $1 \mathrm{ml} /$ minute.

The method employed allows simultaneous analysis of glucosinolates at a very low glucosinolate level and analysis of fatty acid composition, without losing the original genome of the meristem. There are indications that in the vegetative phase the glucosinolate profile can vary remarkably in the different parts of the plant (SANG et al. 1984). Therefore the concentration of glucosinolates was monitored during the first days of the vegetative phase. The germination time of two days is normally used in the half seed technique for fatty acid analysis.

During the first 20 hours, the concentration of free glucose remained stable below $4 \mu \mathrm{mol} /$ $1 \mathrm{~g}$ fat-free meal after which the concentration increased about fivefold, decreasing again to the original level towards 48 hours. The germination time of 20 hours was, however, sufficient to enable dissection of the meristem. Thus a standard concentration of the free glucose can be used when calculating total glucosinolate concentration.

The glucosinolate concentrations of the single seeds remained in seven out of eight cases below the glucosinolate concentration of 
the standard meal. This was due mainly to the method of homogenization, performed quite simply with a glass rod. Although the dried sample was quite fragile, very small pieces still remained uncrushed.

There are within biotechnology several methods ready for routine laboratory and plant breeding work. Micropropagation, for instance, is one of the most established

\section{References}

Acharya, S., Dueck, J. \& Downey, R. 1983. Selection and heritability studies on Canola/rapeseed for low temperature germination. Can. J. Plant Sci. 63: 377 -384 .

Alpenfels, W. 1981. A rapid and sensitive method for the determination of monosaccharides as their dansyl hydrazones by high-performance liquid chromatography. Anal. Biochem. 144: 153-157.

Appelqvist, L. \& Josefsson, E. 1967. Method for quantitative determination of isothiocyanates and oxazolidinethiones in digest of seed meals of rape and turnip rape. J. Sci. Food Agric. 18: 510-519.

AvıgAD, G. 1977. Dansyhydrazine as a fluorimetric reagent for thinlayer chromatographic analysis of reducing sugars. J. Chromatogr. 139: 343-347.

Beare, J., Gregory, E., \& Campbell, J. 1959. The effect of different varieties of rapeseed oil on weight gains and Golden rape oil on reproduction of the rat. Can. J. Biochem. Physiol 37: 1191-1195.

Bowland, J., Zivkovic, S. \& Manns, J. 1963. Solvent extracted rapeseed oil meal as a protein source for pigs and rats. Can. J. Anim. Sci. 43: 252-284.

Daun, J., McGregor, D. 1981. Glucosinolate analysis of rapeseed (Canola). Method of the Canadian Grain Commission. Grain Research Laboratory. Agriculture Canada.

Dorrel, D. \& Downey, R. 1964. The inheritance of erucic acid content in rapeseed (Brassica campestris). Can. J. Plant Sci. 44: 499-504.

EGgert, F. \& Jones, M. 1985. Measurement of neutral sugars in glycoproteins as dansyl derivatives by automated high-performance liquid chromatography. J. Chromatogr. 333: 123-131.

Gamborg, O., Miller, R. \& Oлima, K. 1968. Nutrient requirements of suspension cultures of soybean root cells. Exp. Cell Res. 50: 151-158. methods and is already used in industrial scale. Combined with micropropagation (and other cell and tissue culture techniques), this method offers the plant breeder a powerful and accurate tool for more satisfactory and rapid results.

Acknowledgements: The author wishes to thank Mrs Maija-Liisa Penttilä and Mr Pertti Kaven for excellent technical assistance.
Heaney, R. \& Fenwick, G. 1981. A micro-column method for the rapid determination of total glucosinolate content of Cruciferous material. Z. Pflanzenzüchtg. 87: 89-95.

JÜRGES, K. \& Thies, W. 1980. Quantitative Analyse des Indol-Glucosinolat Gehaltes in Samen und Blăttern von Brassica napus und B. campestris. Z. Pflanzenzüchtg. 84: $168-178$.

Lein, K. \& SChÓN, W. 1969. Quantitative Glucosinolatbestimmung aus Halbkörnern von Brassica-Arten. Angew. Botanik XLIII: 87-92.

Mopper, K. \& Johansson, L. 1983. Reversed-phase liquid chromatographic analysis of Dns-sugars. Optimization of derivatization and chromatographic procedures and applications to natural samples. J. Chromatogr. 256: $27-38$.

Murashige, T. \& Skoog, F. 1962. A revised medium for rapid growth and bioassays with tobacco tissue cultures. Physiol. Plant. 15: 473-497.

Sang, J. Minchinton, I., Jonstone, P. \& Truscott, R. 1984. Glucosinolate profiles in the seed, root and leaf tissue of cabbage, mustard, rapeseed, radish and swede. Can. J. Plant Sci. 64: 77-93.

SCHwimmer, S. 1961. Spectral changes during the action of myrosinase on sinigrin. Acta Chem. Scand. 15: 535-544.

THIEs, W. 1968. Die Biogenese von Linol- und Linolensăure in den Samen höherer Pflanzen, insbesondere Raps und Rübsen, als Problem der Ölpflanzenzüchtung. Angew. Botanik XLII: $140-154$.

- 1976. Quantitative gas-liquid chromatography of glucosinolates on the microliter scale. Fette, Seifen, Anstrichmittel 78: 231-234.

Ms received January 21, 1988 
Rasvahappojen ja glukosinolaattien

analyysi yhdestä rypsin (B. campestris L.)

siemenestä yhdistettynä genotyypin

säilyttämiseen saman siemenen meristeemi-

viljelmän avulla

\section{Seppo Sorvari}

Kasvinjalostusosasto, Maatalouden tutkimuskeskus, 31600 Jokioinen

Käyttämällä n.k. puolisiemen-menetelmäă on rypsi- ja rapsilajikkeiden jalostuksessa saavutettu hyviä tuloksia pitkäketjuisten rasvahappojen kuten esim. erukkahapon (C22:1) pitoisuuden alentamisessa. Tässă menetelmässä idätetäăn siementä $1-2$ vrk, jonka jälkeen ulompi sirkkalehti irroitetaan ja sen sisältämät rasvahapot analysoidaan kaasukromatografisesti.

Niin kutsutuilla yksinolla-lajikkeilla, joilla glukosinolaattien pitoisuudet ovat korkeita, voidaan periaatteessa samasta sirkkalehdestä mitata myös glukosinolaattien pitoisuus. Mutta koska nykyaaän viljelyssä on lăhes yksinomaan n.k. kaksoisnolla-lajikkeita, ei aiemmin käytettyjen menetelmien herkkyys enäă riitä glukosinolaateille puolisiemen-analyysissä.

Sen vuoksi oli tămăn tutkimuksen lähtökohtana se, kuinka voidaan nykyaikaisesta kaksoisnolla-lajikkeesta mitata samanaikaisesti yhdestä siemenestä sekä rasvahappokoostumus, ettă glukosinolaattipitoisuus menettämăttă alkuperäistä genomia. Analyysiä varten kehitettiin bioteknis-analyyttinen menetelmă, jossa alkuperäinen genomi otetaan talteen kasvattamalla siemenen meristeemistä uusi kasvi ja analysoimalla loppusiemen glukosinolaattien ja rasvahappojen suhteen. Lisăksi glukosinolaattien analyysiä varten sovellettiin uusi erittäin herkkä analyysimenetelmă, jossa hydrolyysin kautta glukosinolaateista vapautuva glukoosi leimataan dansyylihydratsiinilla ja pitoisuus mitataan nestekromatografilla. Menetelmällă voidaan mitata UV-alueella pikogramma pitoisuuksia, mutta käytettãessă fluoresenssi mittausta voidaan herkkyys nostaa n. sata-kertaiseksi. 